Fig. 4 again shows the island in its winter garb, and is from a drawing made by Lieut. Ring, R.N., when commanding the sealer Capella.

"We have Sars's crater, on the slope shelving to wards Cape North-East ; we see, too, the great glaciers on the north side, also Cape North-West and Muyen's Cross Cape, in a line with the point of view; and the low tract of the island, with the heights of the southern part, are boldly defined in the picture. The crater of Beerenberg, with its sunken edge on the north side, is also seen, and lower down a huge, cauldron-shaped depression, from which the great northern glaciers take their origia."

Some very interesting mineralogical specimens were brought from Jan Mayen, on which Mr. H. Reusch, of the Norwegian Geological Survey, reports. We reproduce illustrations of four specimens of olivine in basalt.

In Fig. 5 the surrounding rock exhibits a remarkably fine granulation in immediate proximity to the çrystals, which it pierces in sac-like ramifications. In Fig. 6 discoloured glass is seen piercing the crystal from the surrounding rock, which has a fine granulation. In Fig. 7 the surrounding base is finely granulated. At the top of the figure is seen basalt of the dominant degree of granulation. Discoloured glass pierces the crystal from the rock surrounding it. In Fig. 8 the iron ore occurring as rod-shaped corpuscles has a definite position towards the crystal of olivine.--Magnified 360 diameters.

Dr. Mohn concludes his instructive account of the geography of this fruitful expedition by some brief observations on Bear Island and Spitzbergen, at various points of which the Voringen touched.

\section{SCIENCE AT CAMBRIDGE}

WE understand that Dr. M. Foster, who, upon his appointment as Professor of Physiology at Cambridge, ceased to be Prælestor at Trinity College, addressed to the Master of Trinity the following letter, which perhaps may interest those of our readers who are not acquainted with the peculiar organisation of our old Universities.

Shelford, Cambridge, July 28, 1883

My DEAR MASTER,-The University having done me the honour to appoint me to the newly established Chair of Physiology, my connection with the College as Prælector comes to an end, though I rejoice that I am still counted among the Fellows of the Society. I cannot let this opportunity pass without making some attempt to thank you, and through you the College, for all you have done for me during the thirteen years of my Prælectorship. You called me, a comparatively unknown young man, to the College in I870; you not only at once gave me leave to follow out my own views as to what I ought to do, but from that time onward have constantly supported me, not simply with cordial approbation, but also with most material assistance.

I have reason to believe that many persons not conversant with the orgarisation and working of the University, are under the impression that the necessary expenses which my work has entailed hive been provided out of University funds. But I am sure that the authorities of the University would be the last to wish that anything done by the College should be considered as done by the University. And as a matter of fact, when I say that I was allowed the use for four years of one room, and for ten years of two rooms, in the University buildings, and that during the last three years I have enjoyed the advantages of the admirable laboratory which has been built for me, with use of gas and water, I have mentioned all that $I$ have received from the University, with the exception of grant of microscopes to the late Prof. Balfour and myself in common. Not only my own remuneration has come from the Colle ${ }^{2}$, but all the really large expenditure involved in my teashing physi- ology, save what has been met by the fees of the students, has been provided for in one way or another by the College.

At the outset the College gave me a large grant of money for apparatus, and some years afterwards a second smaller grant. During the whole thirteen years I have received from the College an annual sum for the payment of my laboratory servants ; and for several years past two demonstrators (one at a comparatively high salary), as well as during the past year three assistant demonstrators, have been paid partly from the tuition fund of the College, partly by funds which, though furnished by private liberality, cannot be wholly dissociated from the College. I think I may fairly say that I have never asked anything of you in vain. I might add that what you have done for me did not prevent you from also assisting our lamented Balfour, working in a closely allied branch of science, or, upon his sat death, from affording material help in carrying on the work which he left behind through aid given to Mr. Adam Sedgwick.

Let me assure you that I fully appreciate all the College has done for me; but perhaps after all I feel still more keenly the sympathy and kindness with which as a stranger I was first received among you, and which have made the thirteen years of my Prælectorship the brightest as well as the best years of my life.

Yours ever truly,

M. FOSTER

\section{THE ISCHIA EARTHQUAKE}

A SLIGHT shock of earthquake occurred in Casamicciola at seven o'clock on Sunday morning, at the Gurgitello, where that of July 28 created the most ruin, but it was limited to that spot, and caused no damage. It is reported that a fissure a kilometre in length and thirty kilometres in depth has opened on the south-west flank of Mount Epomeo. The smo'ze ejected from the fumaroli at the summit of the mountain has considerably diminished in quantity. The Naples Academy of Sciences has appointed a Commission to investigate the telluric conditions of Ischia.

The following communication from the Times correspondent at Rome is important :-

"From a second report made by Prof. Michele Stefano di Rossi, head of the Central Geodynamic Observatory at Rome, to the Minister of Agriculture, on the phenomena connected with the earthquake in Ischia, it appears that not only were there for some days beforehand very distinct premonitory signs at Casamicciola of the impending catastrophe, but that throughout the peninsula forewarnings, identical in character, were numerous and widespread. On the island of Ischia there was an extraordinary increase in the temperature of the thermal waters and in the violence of the fumaroli (i.e. the natural smoke funnels) at the spot called Monte Cito. These phenomena were noticed eight days before the catastrophe occurred. On these important points the evidence which Prof. di Rossi obtained is abundant. There is less conclusive testimony concerning the shrinking and consequent scarcity of the drinking water in the wells. But he has absolutely certified that, commencing from a period a fortnight anterior to July 28 , many slight shocks of earthquake, of almost daily recurrence, were felt, and subterranean rumblings were
heard. Phenomena identical with these preceded the earthquakes in Ischia in I828, I85 I, and I88I; and Prof. di Rossi emphatically states that had an observatory been established in Ischia after the earthquake of I88I, according to the advice he then gave, and the phenomena which manifested themselves at Cassamicciola from July 20 onwards been communicated to him at the Central Observatory in Rome, he would not have hesitated an instant in pointing out the imminent danger of an impending 